\title{
Impact of Charcoal Production on Biodiversity in Togo (West Africa)
}

\author{
Jérémie Kokou Fontodji ${ }^{1}$, Honam Atsri ${ }^{1}$, Kossi Adjonou ${ }^{1}$, Aboudou \\ Raoufou Radji ${ }^{1}$, Adzo Dzifa Kokutse ${ }^{1}$, Yaovi Nuto ${ }^{2}$ and Kouami Kokou ${ }^{1}$ \\ ${ }^{1}$ Laboratoire de Botanique et Ecologie Végétale, Faculté des Sciences, \\ Université de Lomé, BP 1515, Lomé \\ ${ }^{2}$ Département de Zoologie, Faculté des Sciences, \\ Université de Lomé, BP 1515, Lomé \\ Togo
}

\section{Introduction}

In Togo, firewood and charcoal contribute more than $80 \%$ to the total domestic energy requirements (Kokou et al., 2009). This traditional energy represents about an annual average consumption of 419,964 tons per year on national level (Fontodji, 2007). This incessant growing request for traditional energy is ensured by national production. Unfortunately, this important consumption of charcoal had enormous consequences on the ecosystems since the methods used by the producers and the consumption modes of charcoal by households still remain archaic. Indeed, the production yield is about 15 to $20 \%$ i.e. 150 to $200 \mathrm{~kg}$ of wood produced per ton of woody material (Girard, 2002) and during the cooking with charcoal, the loss in energy is about 8 to 13\% (Thiam, 1991). This situation is an important waste of wood causing the felling of a great number of trees. Moreover, the producers claim that the charcoal is of good quality when part of the wood used is fresh. Therefore, the excessive exploitation of the forestry resources for energy purposes puts an important pressure on the ecosystems and leads consequently to serious harmful effects on the environment and the biodiversity preservation. The objectives of this article are: (1) to analyze the impact of charcoal production on the natural ecosystems; (2) to assess the pressure on the key plant species as well as (3) on the soil physico-chemical properties soil and fauna diversity inside the kilns; (4) to assess how national environment policies and laws regulate charcoal production activities.

\section{Material and methodology}

\subsection{Socio-economic and environmental status of Togo}

Togo is situated on the coast of the Benin Gulf (Fig. 1). It has an area of $56,600 \mathrm{~km}^{2}$ and is bordered at the south by the Atlantic Ocean, at the north by Burkina Faso, at the east by Benin Republic and at the west by Ghana. Situated between the $6^{\circ}$ and $11^{\circ}$ of latitude north and between $0^{\circ}$ and $2^{\circ}$ of longitude east, the country stretches over $600 \mathrm{~km}$ from north to south, and over $50 \mathrm{~km}$ from east to west (at the level of the coast). Its landscape is generally 
flat, except the Atakora range which crosses it diagonally from the south-west to the northeast, with tops reaching sometimes $900 \mathrm{~m}$ in the southern part.

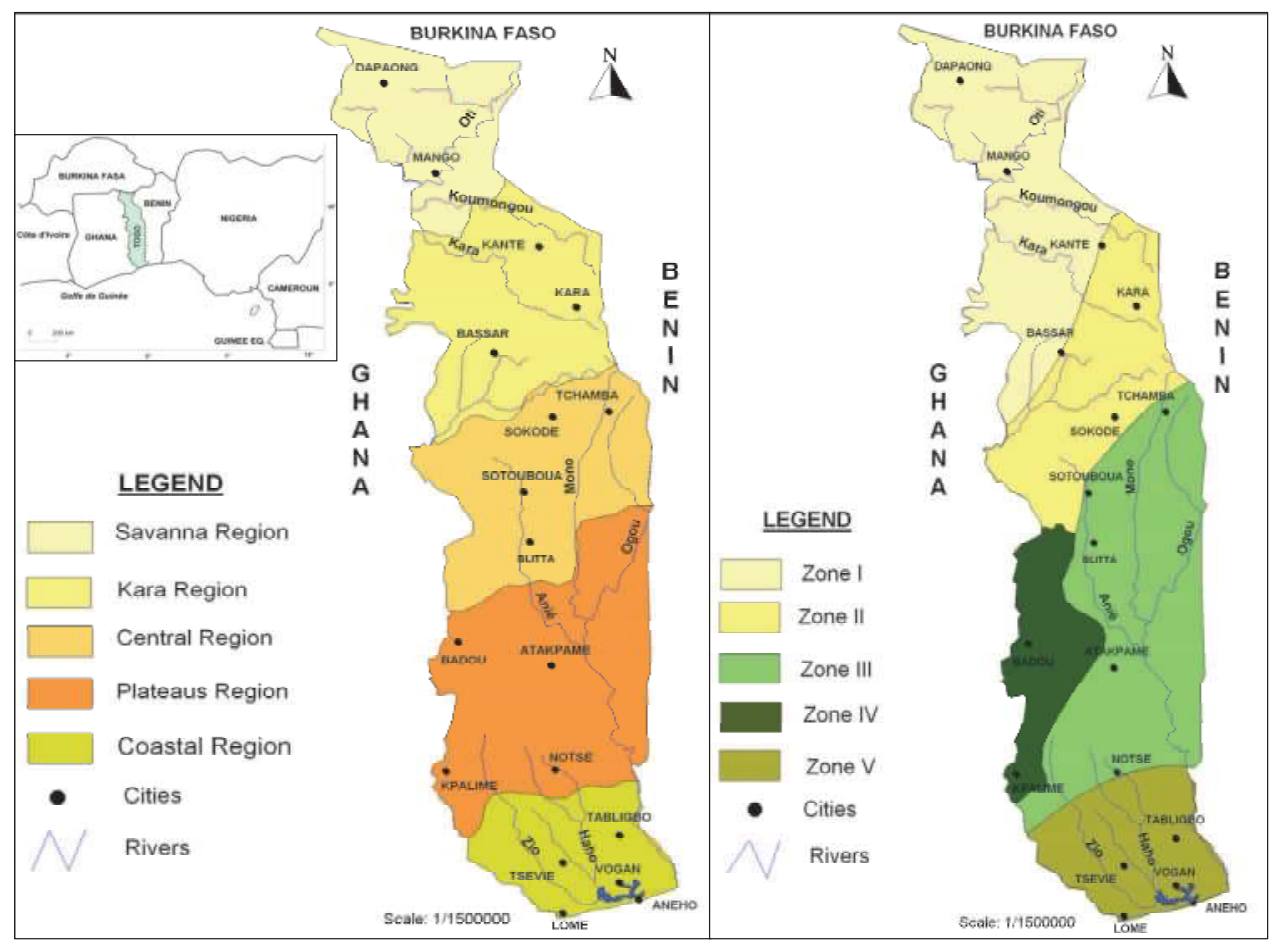

Fig. 1. Administrative regions (left) and phytogeographical zones (right) of Togo. Legend. Zone I: Refers to the plains in the north with a sudanian climate characterized by a rainy season running from June to October and a dry season from November to May, with an average of 6-7 dry months. Total rainfall is between 800 and $1000 \mathrm{~mm}$. The predominant vegetation is Sudanian savanna. Zone II: Concerns the hilly dry forest and savannah mosaic zones in the north with a soudano-guinean climate including cool nights at elevated regions, and with a rainy season from April to October and a dry season from October to March, characterized by the harmattan. Yearly rainfall is $1200-1300 \mathrm{~mm}$, but is very irregular within the year and between years. Zone III: Concerns Guinean savanna in the plains in the centre of the country having a tropical climate characterized by a rainy season from May till October and a dry season of at least 4 months. Total rainfall is between 1200 and $1500 \mathrm{~mm}$ per year. The savanna of Central Togo is interspersed with islands of semi-deciduous forest in the southern part and with dry forest in the northern parts. Zone IV: Corresponds to the southern part of Togo Mountains with a transitional subequatorial climate characterized by a long rainy season occurring from March to October and disrupted by a slight decrease in rainfall in August or September. The rainfall amounts range from 1300 to $1600 \mathrm{~mm}$ per year. Here, semi-deciduous moist forests are the major vegetation type. Zone V: Refers to the coastal plain in the south under a subequatorial climate characterized by a shortage of rainfall in the coastal part $(800 \mathrm{~mm} /$ year in Lomé, the capital). The landscape offers a mosaic of savanna, agricultural land and preserved forest. Islands of dry semi-deciduous forest are found mainly as sacred forest or as classified forest. 
The country is divided into five ecological zones (Ern, 1979). It is also subdivided into five administrative regions (Fig. 1). The impact of poverty is estimated at $61.7 \%$ of the population. Poverty is essentially found in rural areas where the impact is of $74.3 \%$. Poverty in rural areas is very acute in the Savanna, Central and Kara regions with respective impacts of $92.5 \%, 84 \%$, and $80 \%$. There is a rapid tendency of urbanization, caused by a great rural exodus. The Togolese population is extremely young, with a high percentage of women. It is also characterized by an extreme growing poverty (152nd country on 177). The current unemployment rate is estimated between $25 \%$ and $33 \%$. That is why charcoal production is one of the main activities in rural areas all over the country.

\subsection{Surveys}

Investigations have been conducted in four supplying basins of charcoal, SB1, SB2, SB3, and SB4, situated inside the ecological zones I, II, III, and IV, respectively (Fig. 2). First, surveys were conducted with 310 charcoal producers from supply basin. Semi-structured questionnaires, oral interviews and group discussions (focus groups) were held with charcoal producers. Woody species used in making charcoal and the preferred species were identified and their availability was systematically recorded. Data relatives to the quantity of charcoal produced between 2004 and 2008 have been collected in the forest check points and regional directions.

The second step was to carry out relevés in homogeneous geomorphologic and physiognomic units. The number of plots applied lies between 8 and 18 in each basin. A total of 100 relevés were carried out inside the four charcoal production areas. The surface plot covered $900 \mathrm{~m}^{2}(30 \times 30 \mathrm{~m})$. In each plot, all woody species were identified as present/absent. The nomenclature adopted was that of Lebrun \& Stock (1991-1997). In addition, a forest inventory was conducted to measure the dendrometric parameters (circumference and height) of the woody species. The circumference $\geq 10 \mathrm{~cm}$ was measured at breast height $(1.30 \mathrm{~m}$ of soil) by means of a ribbon. For multi-stemmed trees, all the stems have been measured. The height of woody plants has been measured by means of a BlumLeiss. Inside the charcoal production area, 10 plots where randomly selected were five subplots of $25 \mathrm{~m}^{2}(5 \times 5 \mathrm{~m})$ were created (in two of the four corners of each plot) to study the regeneration capability of the species. The regeneration capability in exploited plots has been compared with unexploited plots selected inside the charcoal production areas. In total, 200 subplots (100 unexploited plots and 100 in exploited plots) were registered. The woody species $<10 \mathrm{~cm}$ in circumference are the individuals taken into account in the regeneration. These stems were counted by species and by methods of regeneration (seedling, sprouting or coppicing and suckering).

At the level of the kiln, soil bulk density, total porosity and soil permeability were determined as described by Soltner (1982). The bulk density is a measure of the weight of the soil per unit volume $(\mathrm{g} / \mathrm{cc})$, usually given on an oven-dry $\left(105^{\circ} \mathrm{C}\right)$ basis, while the total porosity was calculated from values of soil bulk density. For instance, organic carbon was evaluated by wet oxidation using the Walkley method (Walkley, 1947). The organic matter content was computed from the organic carbon content through a conversion factor of 1.72. Soil $\mathrm{pH}$ was determined by conventional standard procedures (AFNOR, 1992) in soil water (1:2) medium using digital electronic $\mathrm{pH}$ meter.

Fauna assessment was carried out inside the kiln by microbial biomass quantification and fauna species inventory. The microbial biomass was quantified using the technique of soil 
respiration measurements, i.e. with regard to the amount of $\mathrm{CO}_{2}$ produced (Schinner et al., 1996). First of all, the soil samples were tested with a hand magnifier and the macro organisms were collected. Then, samples were put through a "Berlèse" device to collect smaller arthropods. The experience consisted in placing the soil samples in a funnel fitted with a mesh sieve from 1 to $5 \mathrm{~mm}$ and to expose them to a light source. The insects fleeing the heat, the dryness, and especially the light fall into a becker containing a fixer alcohol $70^{\circ}$ under the funnel. Species were identified using a determination key (Coineau, 1974) and a reference of samples of the University of Lomé (Togo).

The last stage of the study consisted in the review of the texts regulating the charcoal production activity, extended to the laws in use with respect to the protection and environment management. The review was also focused on the action plan of the forestry sector. The information collected were completed with the discussions with the Regional Directors of the Environment and the Office de Développement et d'Exploitation des Forêts $(O D E F)$, which is the national institution in charge of charcoal production and trade in Togo.

\section{Impact of the charcoal production on the natural ecosystems}

In Togo, charcoal production is greatly concentrated in the Plateaus, Central, and Savanna Regions (Table 1). It is in those regions that there is still enough vegetation, mostly in the Plateaus Region because of its forests. On the other hand, natural vegetation is almost inexistent in the Kara and Coastal regions. Kara Region is one of the regions where charcoal production was very high but which today is the region where the quantity of charcoal produced is lowest because of the poor vegetation.

\begin{tabular}{|l|l|l|l|l|l|}
\hline \multirow{2}{*}{ Region } & \multicolumn{5}{|c|}{ Year } \\
\cline { 2 - 7 } & 2004 & 2005 & 2006 & 2007 & 2008 \\
\hline Coastal & $7,845.6$ & $5,238.3$ & - & - & - \\
\hline Plateaus & $44,785.2$ & $23,314.2$ & - & - & $23,825.4$ \\
\hline Central & $19,873.5$ & 12,027 & $37,441.8$ & $46,042.5$ & $72,312.3$ \\
\hline Kara & $1,613.4$ & 75 & - & - & 127.9 \\
\hline Savannas & - & - & $8,403.3$ & $10,170.9$ & $12,009.9$ \\
\hline
\end{tabular}

Table 1. Quantity of charcoal produced per region (in tons) -: Data not available

The extent of charcoal production during these past years in Togo is becoming more and more alarming. For instance, the average production of charcoal on national level, calculated over five years (2004-2008), is of 419,963.8 $\pm 47,896.5$ tons per year (Table 2).

This important consumption of wood is one of the main reasons of deforestation and vegetation degradation in Togo, especially in Plateaus, Central and Savanna regions considered as the main basins of provision in the country (Table 1). The woody plant biomass destroyed by this activity is about 2,799,759 tons per year (Table 2). MEMEPT (2002) indicates that logging for fuel wood is the third reason of the deforested areas, i.e. 5,000 hectares each year. This high rate of deforestation is changing with population growth; for an average population estimated at 5,596,000 inhabitants, the yearly average consumption per inhabitant is then $75 \mathrm{~kg}$. 


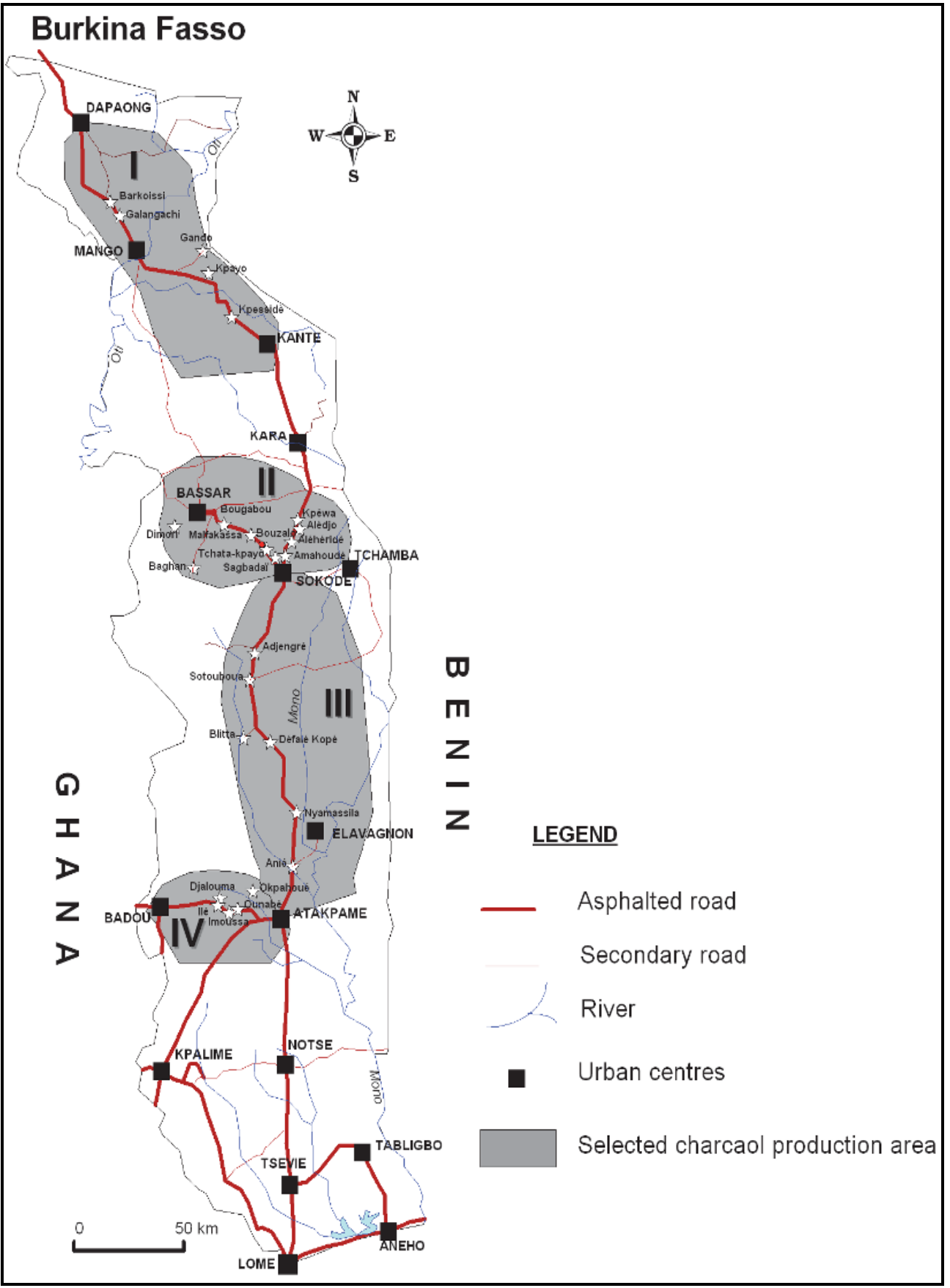

Fig. 2. Location of charcoal production areas in the phytogeographical zones of Togo 


\begin{tabular}{|l|l|l|l|l|}
\hline Year & $\begin{array}{l}\text { Quantity of } \\
\text { charcoal } \\
\text { controlled toward } \\
\text { Lomé (tons) }\end{array}$ & $\begin{array}{l}\text { Quantity of } \\
\text { charcoal controlled } \\
\text { at the national } \\
\text { level (tons) }\end{array}$ & $\begin{array}{l}\text { Real quantity of } \\
\text { charcoal } \\
\text { produced at the } \\
\text { national2 level } \\
\text { (tons) }\end{array}$ & $\begin{array}{l}\text { Quantity of wood } \\
\text { destroyed }^{3} \text { (tons) }\end{array}$ \\
\hline 2004 & $62,017.4$ & 151,262 & $453,785.9$ & $3,025,239.3$ \\
\hline 2005 & $54,056.9$ & $131,846.1$ & $395,538.3$ & $2,636,922.0$ \\
\hline 2006 & 51,140 & $124,731.7$ & $374,195.1$ & $2,494,634.0$ \\
\hline 2007 & $53,269.8$ & $129,926.3$ & 389,779 & $2,598,526.8$ \\
\hline 2008 & $66,491.2$ & $162,173.7$ & 486,521 & $3,243,473.3$ \\
\hline $\begin{array}{l}\text { Average } \\
\text { per year }\end{array}$ & $57,395.06 \pm 6,545.9$ & $139,987.95 \pm 15,965.5$ & $419,963.8 \pm 47,896.5$ & $2,799,759.1 \pm 319310$ \\
\hline
\end{tabular}

${ }^{1}$ Calculated on the basis of the data from the check points at the entry of Lomé, capital of Togo; it represents $41 \%$ of charcoal trade in Togo (MEMEPT, 2002)

${ }^{2}$ Estimation on the basis of the results of surveys; only a third of charcoal toward Lomé is controlled ${ }^{3}$ Calculated on the basis of the minimum output of wood carbonization, i.e. 15\% (Thiam, 1991)

Table 2. Assessment of the quantity of charcoal produced/consumed on national level

This situation affects particularly protected areas in Togo. For instance, in the Savanna Region (ecological zone I), the most affected protected area is the Oti-Keran National Park (OKNP). The production of charcoal is the main activity that weighs today on the park while formerly it was just the activity of some few women to cater for their needs. But today, charcoal production is the main activity around the OKNP (Fig. 3), especially produced by fresh wood felled from the park. Charcoal depots in sacs of 50 and $100 \mathrm{~kg}$ can be counted by dozens inside and around the park (Fig. 4).

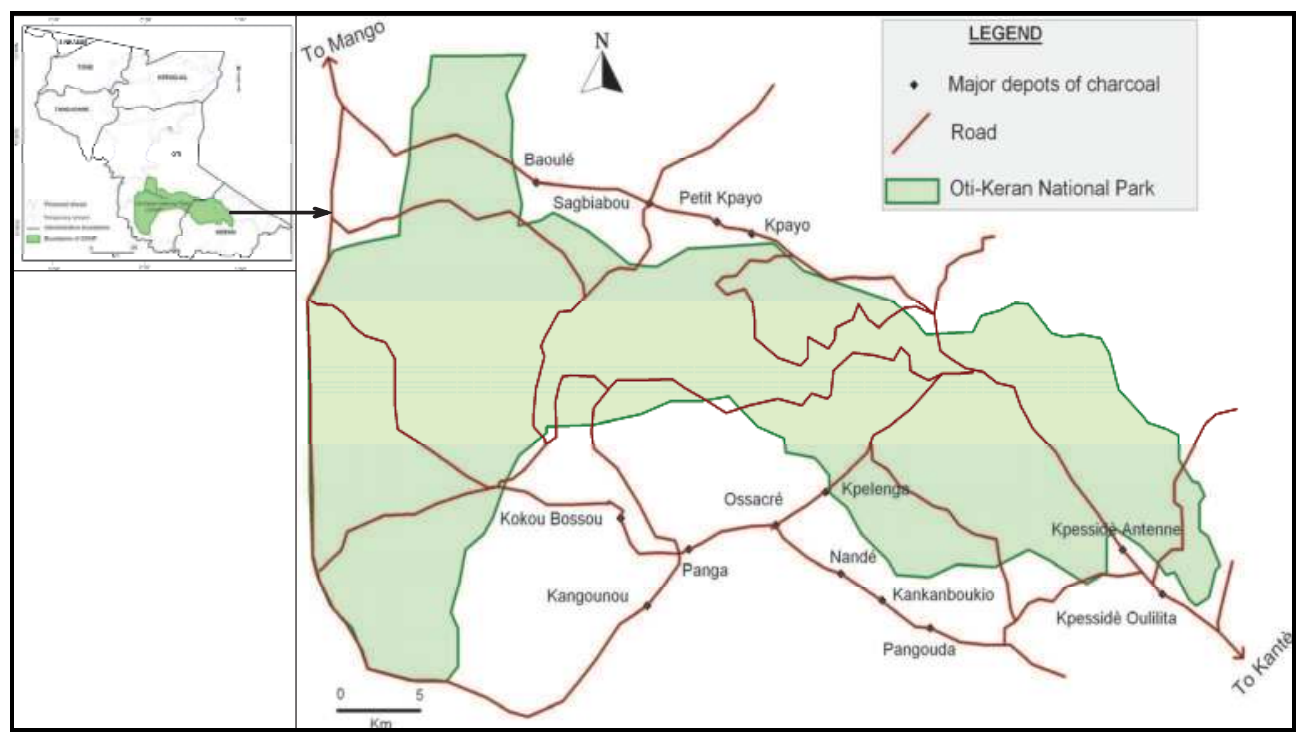

Fig. 3. Main charcoal depots inside and around Oti-Keran National Park 


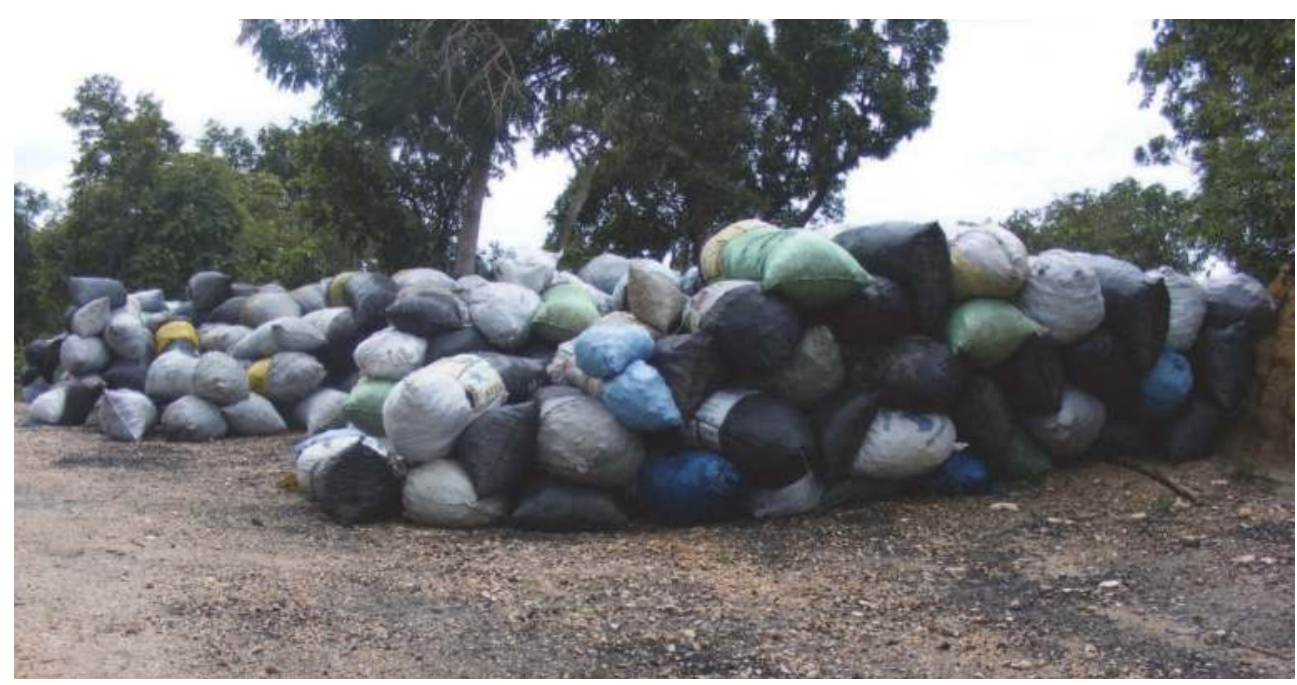

Fig. 4. Depot of a week's production by a village of 200 people, to be loaded to town

\section{Impact on plants species used in charcoal production}

During a survey in the main charcoal production basin in Togo, Kokou et al. (2009) found that the production is focused on 15 native plant species classified as the species of the first choice or species of category 1 among which Anogeissus leiocarpa, Erythrophleum suaveolens, Prosopis africana, Burkea africana, Detarium microcarpum, Lophira lanceolata, Vitellaria paradoxa, etc. (Table 3). In areas of Sudanian savanna and dry forest, A. leiocarpa, L. lanceolata, B. africana, $V$. paradoxa and $P$. africana are by far the most exploited species which provide the best wood for charcoal production. In Guinean savanna and semi-deciduous forest areas, $E$. suaveolens is added to these "key" species. The interest shown in these species is related to the quality of their charcoal, which is highly valued by the consumers in the cities. Due to a lack of adequate policy in reforestation in Togo, these species are overexploited and many of them become rare. The charcoal producers are of the view that highly valued species (Afzelia africana, L. lanceolata and P. africana), are no more available.

Apart from these first choice species, others are increasingly being exploited because of their availability. These species are mainly used by default because, a decade ago, were not used in charcoal production in Togo. These species exploited by default or species of category 2 or alternative species [sometimes with very small diameter, inferior to $3 \mathrm{~cm}$ ]. They are 19 of number, among which Cola gigantea, Gmelina arborea, Parinari curatellifolia, Parkia biglobosa, Tectona grandis, Diospyros mespiliformis, etc. (Table 4). The use of these species of the second category, mainly those used in reforestation such as teak, is an alternative towards the reduction of the current pressure on natural vegetation. The choice of the resource is not only related to the energy quality but also to the availability. Therefore 34 woody species are popularly used for charcoal production. Two families (Caesalpinaceae and Combretaceae) consist of $60 \%$ of these species.

In terms of the regeneration of the resources on the field, two most common types of regeneration of these species are seedlings and coppices (Kokou et al., 2009). The highest densities are observed in both types of regeneration all over the charcoal production areas. 
Inside Sudanian savanna and dry forest areas, the densities are very high and can double after exploitation. Inside Guinean savanna and semi-deciduous forest, density differences are not so high. After exploitation, coppicing becomes the preferred method of regeneration of the stumps inside all the charcoal production areas. In the Sudanian savanna and dry forest areas, the exploitation lead to suckering that resulted in doubling or tripling of densities. Inside the unexploited areas, the distribution of the regeneration, all methods inclusive, is inconsistent (Fig. 5). The high penetration of light due to the destruction of part of the woody biomass favours the germination of seed stock of exploited species. These results are consistent with those of Ouédraogo (2006) in Sudanian savannas and those of Neke et al. (2006) in South Africa, which revealed that the high numbers of seedlings may be due to a response to the thinning of the woodland and the opening up of the canopy through harvesting.

\begin{tabular}{|c|c|c|c|c|c|c|c|c|}
\hline \multirow[t]{3}{*}{ Species } & \multicolumn{8}{|c|}{ Diversity Index of the charcoal plant species } \\
\hline & \multicolumn{2}{|l|}{ SB1 } & \multicolumn{2}{|c|}{ SB2 } & \multicolumn{2}{|c|}{ SB3 } & \multicolumn{2}{|l|}{ SB4 } \\
\hline & $N_{u}$ & IVI & $N_{u}$ & IVI & $N_{u}$ & IVI & $N_{u}$ & IVI \\
\hline Anogeissus leiocarpus & $79 \mathrm{~d}$ & 44.6 & & & $96^{d}$ & 15.1 & 70pd & 50 \\
\hline Afzelia africana & $27.4 \mathrm{pd}$ & 0 & $20.6^{d}$ & 22.4 & & 8.6 & 30pd & 37.5 \\
\hline Burkea africana & $72.6^{\mathrm{d}}$ & 75.9 & $67.6^{\mathrm{d}}$ & 37.4 & $50^{\mathrm{d}}$ & 39.1 & 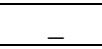 & 14.2 \\
\hline Canthium schimperianum & & & 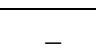 & & & & $16.3^{\mathrm{d}}$ & 0 \\
\hline Combretum spp. & $8.8^{\mathrm{td} ; \mathrm{d}}$ & 89.2 & - & 30.2 & $21^{\text {td }}$ & 14.5 & $37.5^{\text {td }}$ & 28.5 \\
\hline Crossopteryx febrifuga & _ & 58 & _ & 65.5 & _ & 14.5 & $25^{\mathrm{d}}$ & 70.1 \\
\hline Detarium microcarpum & $50.1^{\mathrm{td}}$ & 58.8 & $75^{\text {td }}$ & 94.2 & _ & 6.3 & & 0 \\
\hline Dialium guineense & - & _ & - & - & 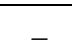 & 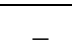 & $13.8^{\mathrm{d}}$ & 0 \\
\hline Erythrophleum suaveolens & 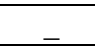 & 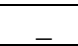 & - & 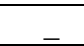 & $88^{\mathrm{d}}$ & 0 & $68.8 \mathrm{pd}$ & 64.9 \\
\hline Lophira lanceolata & $53.2^{\mathrm{d}}$ & 0 & - & 63.7 & $37 \mathrm{~d}$ & 28.8 & $42.5^{\mathrm{d}}$ & 43.2 \\
\hline Prosopis africana & $88.7^{\mathrm{d}}$ & 6.3 & $82.4^{\mathrm{d}}$ & 15.2 & $64 \mathrm{pd}$ & 12.5 & $26.3^{d}$ & 0 \\
\hline Pterocarpus erinaceus & $48.4^{\mathrm{d}}$ & 53 & $8.8^{\mathrm{d}}$ & 32.9 & 60pd & 78.6 & $50^{d}$ & 29.1 \\
\hline Terminalia glaucescens & _ & 53.9 & $73.5^{\mathrm{td}}$ & 71.7 & _- & 62.5 & $36.3^{\mathrm{d}}$ & 18.9 \\
\hline Terminalia laxiflora & 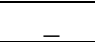 & - & & & $33^{\mathrm{d}}$ & 16.1 & & 0 \\
\hline Vitellaria paradoxa & $56.1^{\mathrm{td}}$ & 46.4 & $20.6^{\mathrm{d}}$ & 59 & $87 \mathrm{~d}$ & 52.3 & $37.5^{\mathrm{d}}$ & 0 \\
\hline
\end{tabular}

Table 3. Preferred species for charcoal production in Togo (Category 1)

SB: Supply Basin; _: species non quoted by the producers; td: very available; d: available; pd: little available; $N_{u}=\frac{N_{u i}}{N_{t 1}} \times 100\left(N_{u i}=\right.$ Level of use of the species, $N_{t 1}$ number of people interviewed in favour of the use of the species, and $N_{t 1}$ : total number of respondents in each supply Basin in Togo) [Equation 1]; Importance Value Index (IVI) per species is obtained by the relationship IVI relative density + relative frequency + relative dominance [Equation 2], (relative density $D_{r}=100 x \frac{N_{i}}{N_{t 2}}$ [Equation 3], where $N_{i}=$ number of individuals of $i$ species; relative frequency $F_{r}=100 x \frac{N_{r}}{N_{t 3}}$ [Equation 4], where $N_{r}=$ number of plots in which the I species is present and $N_{t 3}=$ total number of relevés; relative dominance $D_{o r}=100 x \frac{g_{i}}{G_{T}}$ [Equation 5], where gi $=$ total basal area of a species and GT $=$ total basal area of all species 


\begin{tabular}{|c|c|c|c|c|c|c|c|c|}
\hline \multirow[t]{3}{*}{ Species } & \multicolumn{8}{|c|}{ Diversity Index of the charcoal plant species } \\
\hline & \multicolumn{2}{|l|}{ SB1 } & \multicolumn{2}{|l|}{$S B 2$} & \multicolumn{2}{|l|}{ SB3 } & \multicolumn{2}{|l|}{ SB4 } \\
\hline & $N_{u}$ & $I V I$ & $N_{u}$ & $I V I$ & $N_{u}$ & $I V I$ & $N_{u}$ & $I V I$ \\
\hline Afromorsia laxiflora & $24.2^{\mathrm{d}}$ & 0 & - & 21 & - & - & - & - \\
\hline Albizia spp. & - & - & - & 5.6 & - & 12.5 & $15^{\mathrm{d}}$ & 29.2 \\
\hline Bridelia ferruginea & - & 40.9 & - & 17.5 & $24^{\mathrm{td}}$ & 51.8 & - & 28.3 \\
\hline Cola gigantea & - & 6.3 & - & 5.6 & - & 25 & $13.8^{\mathrm{d}}$ & 25.7 \\
\hline Daniellia oliveri & $24.2^{\mathrm{td}}$ & 9.8 & - & 76.5 & $15^{\mathrm{d}}$ & 13.9 & $20^{\text {td }}$ & 23.3 \\
\hline Dichrostachys cinerea & - & 50.8 & - & 55.6 & - & 100 & $20^{\mathrm{td}}$ & 50.7 \\
\hline Diospyros mespiliformis & $29 \mathrm{pd}$ & 13.9 & - & - & $69 \mathrm{pd}$ & 25 & $31.3^{\mathrm{d}}$ & 0 \\
\hline Faurea speciosa & - & - & - & - & - & - & $60^{\text {td }}$ & 16.2 \\
\hline Gmelina arborea & - & 6.3 & - & 21 & - & 37.5 & $33.8^{\mathrm{td}}$ & 0 \\
\hline Hexallobus monopetalus & - & - & - & - & - & - & $27.5^{\mathrm{td}}$ & 0 \\
\hline Hymenocardia acida & - & 13 & - & 38.3 & - & 37.5 & $20^{\text {td }}$ & 41.9 \\
\hline Isoberlinia spp. & - & 14 & $44.1^{\mathrm{td}}$ & 48.5 & - & 51.2 & - & 25 \\
\hline Khaya spp. & $45.2^{\mathrm{d}}$ & 15 & - & 9.4 & $42^{\mathrm{d}}$ & 12.7 & 18.8 pd & 25.3 \\
\hline Parinari curatellifolia & - & 15.2 & - & 46.1 & - & 42.1 & $27.5^{\mathrm{td}}$ & 41.8 \\
\hline Parinari glabra & - & - & - & - & - & - & $11.3^{\mathrm{d}}$ & 56.1 \\
\hline Parkia biglobosa & $21^{\mathrm{td}}$ & 12.9 & - & 5 & - & 12.8 & $17.5^{\mathrm{d}}$ & 13.3 \\
\hline Pseudocedrela kotschyii & - & 20.2 & - & 27.8 & - & 64.9 & $25^{\mathrm{td}}$ & 50 \\
\hline Tectona grandis & - & - & - & 2.1 & $39^{\text {td }}$ & - & - & 25 \\
\hline Vitex doniana & - & - & - & 11.9 & - & - & $20 \mathrm{~d}$ & 2.3 \\
\hline
\end{tabular}

Table 4. Species used by default for charcoal production in Togo (Category 2)

The deterioration of the vegetation in Togo because of the charcoal production activities (Fig. 6) is not a situation unique to Togo but observed generally in the developing countries. Indeed, it has been proved that the extraction of wood from the tropical forests for charcoal production, firewood, and timber constitutes $68 \%$ of the causes of deforestation in Africa, $89 \%$ in Asia and 51\% in Latin America (Geist \& Lambin, 2001). A study conducted by the World Bank in six countries of West Africa, reveals that charcoal production is the main source of deforestation in countries where they produce a lot (Ninnin, 1994). In China, the excessive consumption of charcoal which goes with the population growth is the main source of deforestation (Chen et al., 2005). In Uganda, the high request for charcoal has an incessant pressure on the forest, which leads to a deforestation rate of $600 \mathrm{~km}^{2}$ per year (Banana \& Gombia-Ssembajjwe, 1996) in Uganda. Makundi (2001) relates that $75 \%$ of the destroyed forests are attributable to the consumption of ligneous energy (charcoal and firewood) in Tanzania. 


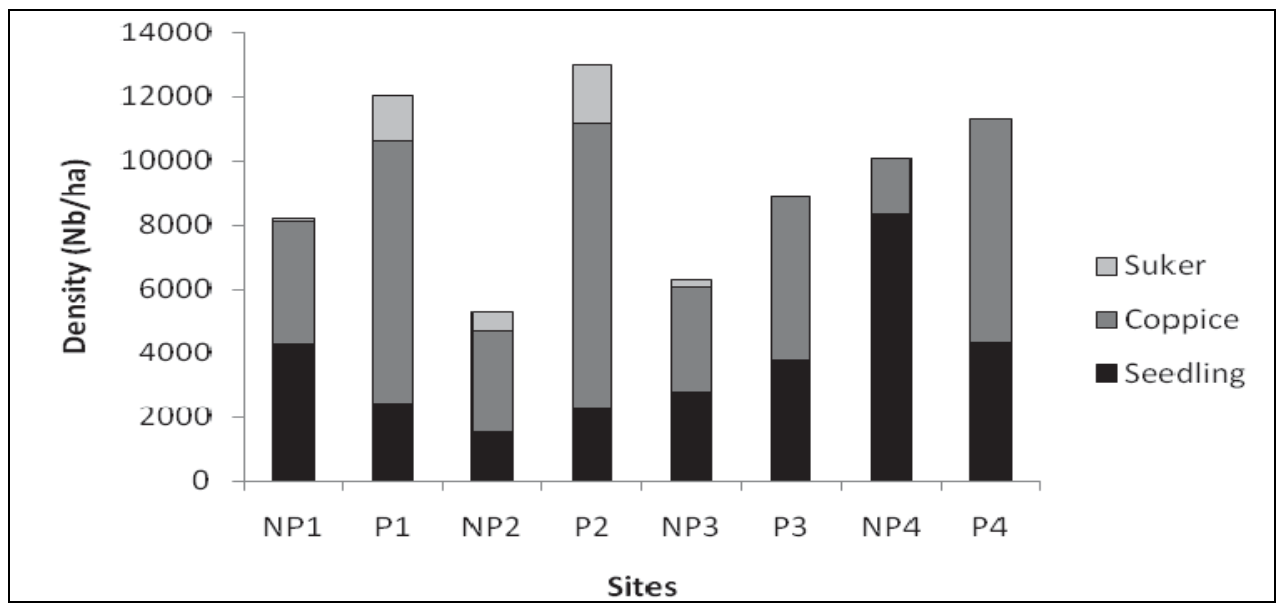

Fig. 5. Mode and density of regeneration in Ps and NPs.

P1: exploited zone in SB1, NP1: unexploited zone in the SB1; P2: exploited zone in SB2, NP2: unexploited zone in SB2; P3: exploited zone in SB3, NP3: unexploited zone in SB3; P4: exploited zone in SB4, NP4: unexploited zone in SB4.

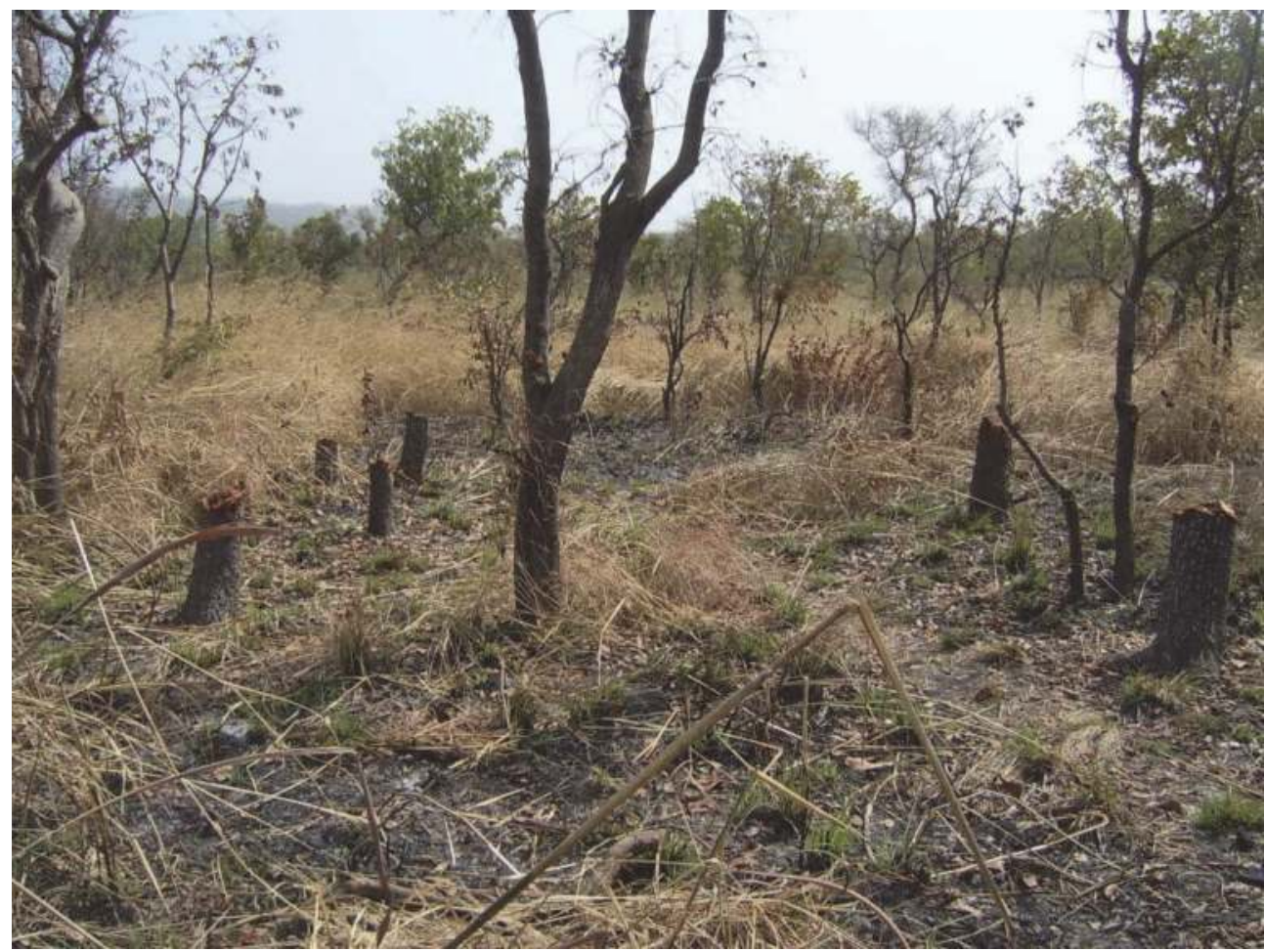

Fig. 6. Exploited area for charcoal production in Sudanian savanna zone 


\section{Impacts of charcoal production on soil properties and biodiversity: Case study of hypogeal soil fauna}

Fontodji et al. (2009) counted and measured the sizes of charcoal kilns in order to know their area and their distribution in the supplying basins in Togo. The results show that the average area of the kilns is of $13.29 \pm 4.4 \mathrm{~m}^{2}$. But the setting up of the kilns needs a total clearing of the vegetation on average area of $11.5 \pm 1.29 \mathrm{~m}^{2}$. The number of kilns per hectare is of $71.5 \pm 18.3$ in average. The area occupied by the kilns on the carbonization site has been estimated at $950.2 \pm 2.73 \mathrm{~m}^{2} /$ ha, that is, approximatively $10 \%$ of the farming areas in charcoal production zones.

After burning, the physico-chemical characteristics soils inside the kilns change, notably the $\mathrm{pH}$ values ranged between 4.61 and 8.00. The values are more important in Guinean area (Guinean savanna and Semi-deciduous forest) than in Sudanian savanna (Table 5). Bulk density was from 1.12 to 1.57 , while the total porosity was between 0.39 and 0.56 and permeability between 0.015 and 0.711 . Bulk density of soil under charcoal kilns decreased as compared to witness plots. The fire increased the permeability at the kilns level by raising the total porosity of soil. Comparing different charcoal production areas, soil total porosity is higher in Guinean savanna area than in Semi-deciduous forest. The total porosity of the soil is more important in Sudanian savanna than in Guinean savanna (Table 6).

\begin{tabular}{|l|c|c|}
\hline $\begin{array}{l}\text { Charcoal } \\
\text { production area }\end{array}$ & Kiln & Witness \\
\hline Sudanian savanna & 5.58 & 5.48 \\
\hline Guinean savanna & 6.11 & 5.23 \\
\hline Semi-deciduous forest & 8.00 & 4.61 \\
\hline
\end{tabular}

Table 5. Soil $\mathrm{pH}$ variability

\begin{tabular}{|l|c|c|c|c|c|c|}
\hline $\begin{array}{l}\text { Soil } \\
\text { characteristic }\end{array}$ & \multicolumn{3}{|c|}{ Kiln } & \multicolumn{3}{c|}{ Witness } \\
\hline $\begin{array}{l}\text { Charcoal } \\
\text { production } \\
\text { area }\end{array}$ & $\begin{array}{c}\text { Permeability } \\
(\mathrm{cm} / \mathrm{mn})\end{array}$ & $\begin{array}{c}\text { Bulk } \\
\text { density } \\
\left(\mathrm{D}^{\prime}\right)\end{array}$ & $\begin{array}{c}\text { Total } \\
\text { Porosity } \\
\left(1-\mathrm{D}^{\prime} / \mathrm{D}\right)\end{array}$ & $\begin{array}{c}\text { Permeability } \\
(\mathrm{cm} / \mathrm{mn})\end{array}$ & $\begin{array}{c}\text { Bulk } \\
\text { density } \\
\left(\mathrm{D}^{\prime}\right)\end{array}$ & $\begin{array}{c}\text { Total } \\
\text { Porosity } \\
\left(1-\mathrm{D}^{\prime} / \mathrm{D}\right)\end{array}$ \\
\hline $\begin{array}{l}\text { Sudanian } \\
\text { savanna }\end{array}$ & 0.022 & 1.46 & 0.438 & 0.015 & 1.575 & 0.394 \\
\hline $\begin{array}{l}\text { Guinean } \\
\text { savanna }\end{array}$ & 0.675 & 1.257 & 0.516 & 0.056 & 1.486 & 0.428 \\
\hline $\begin{array}{l}\text { Semi- } \\
\text { deciduous } \\
\text { forest }\end{array}$ & 0.711 & 1.120 & 0.569 & 0.284 & 1.171 & 0.549 \\
\hline
\end{tabular}

Table 6. Soil bulk density, total porosity and permeability

Fontodji et al. (2009) dealt also with the activity of the soil fauna at the level of the kiln by measuring the change in microbial mass with regard to the amount of $\mathrm{CO}_{2}$ produced (soil respiration). As $\mathrm{CO}_{2}$ evolution in the soil results from the decay of organic matter (soil biological activity), the results of this survey showed that the reduction of $\mathrm{CO}_{2}$ caused by fire is different according to the ecosystem. It is the most important in Sudanian savanna 
(Fig. 7). In savannas (Sudanian or Guinean) the variation in microbial biomass reaches a radius of $15 \mathrm{~m}$ around the kilns while this radius is $5 \mathrm{~m}$ in Semi-deciduous forest.

In addition, the inventory of soil fauna allowed to record 81 micro-organisms belonging essentially to beetles, Hymenoptera, Heteroptera, Diptera, Orthoptera, myriapods, Homoptera, mites, nematodes, Isoptera, etc. The hypogeal biodiversity indexes (average species richness, Shannon average index and average evenness) were more important in Semi-deciduous forest areas than in Sudanian or Guinean savannas (Table 7). Farther moving away from the kilns, greater the species diversity was. The curve representing specific richness $\left(N_{0}\right)$ and Shannon index tend to stabilise beyond a radius of $10 \mathrm{~m}$ from the kiln (Fig. 8). Semi-deciduous forests provided the most microorganisms and Sudanian savannas provided less micro-organism than Guinean savannas. The soil fauna is more diversified in surface than in depth. But in Guinean savanna, the results of this study revealed more diversified fauna in depth than in surface (Fig. 9). This could be explained by the fact that in savannas the surface of soil is completely dried by the effect of the dry season (6 to 8 months of dryness). In the semi-deciduous forests, whatever the season, there is always favorable moisture for the soil fauna because of the abundant waste, which not only keeps this preferential moisture, but serves as nutrients. In savanna, animals of the soil, in search of preferential moisture run off to the depth because of the heat of the dry season. The species are already facing survival difficulties before the event of fire which destroys them completely. In the dry season, the effect of fire only worsens temperature variations that have very serious effects on soil fauna. It is therefore reasonable that the effect of fire be broader in savannas than in forest.

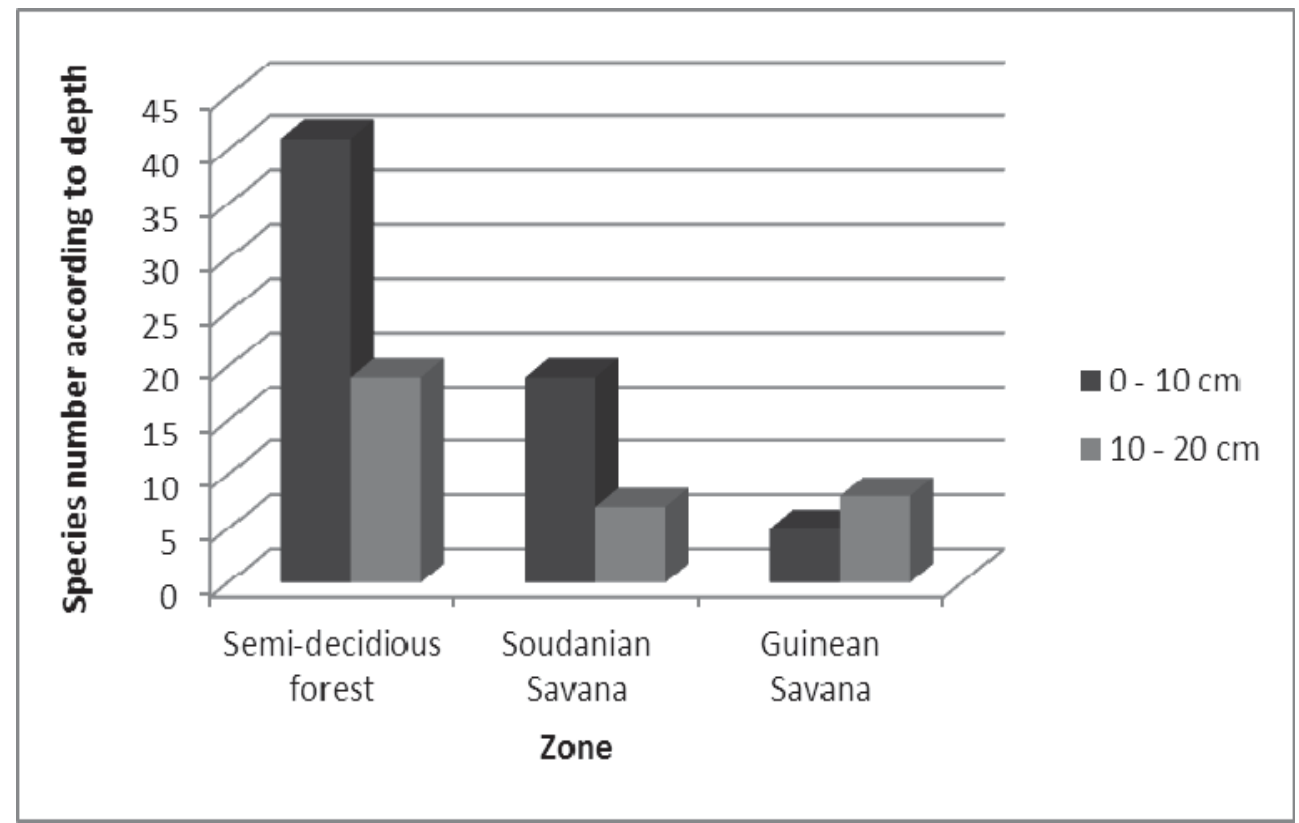

Fig. 7. $\mathrm{CO}_{2}$ variation per zone 


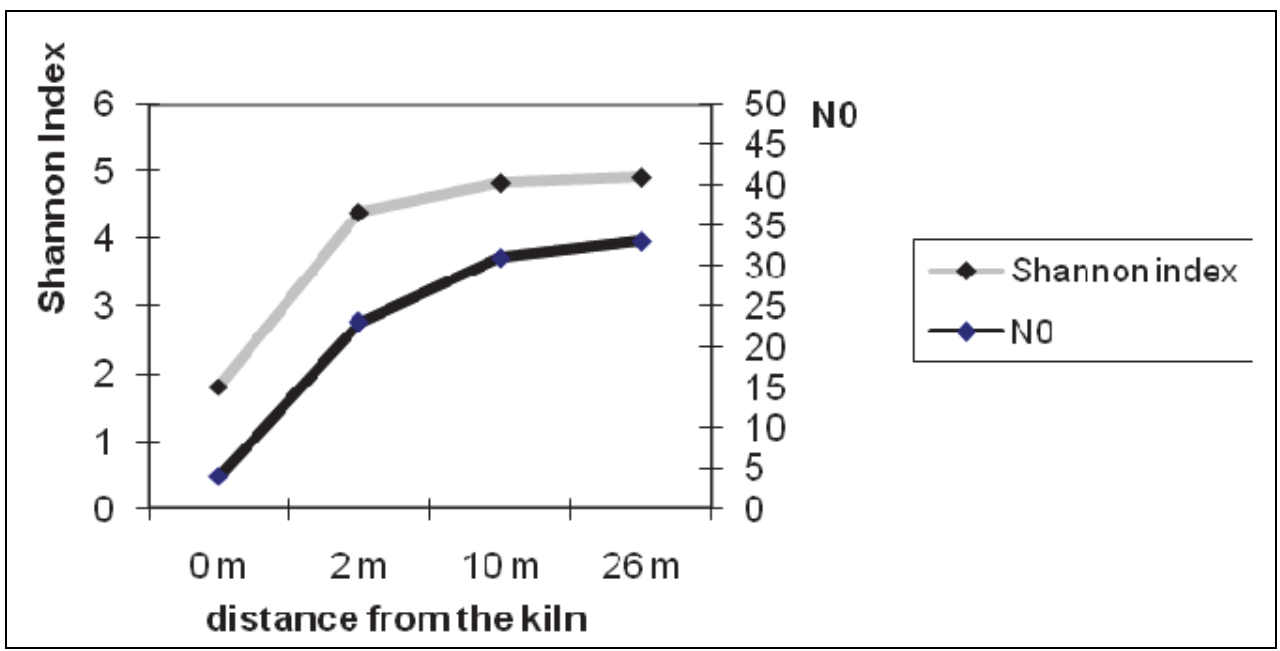

Fig. 8. Variability of diversity index in semi-deciduous forest area

\begin{tabular}{|l|c|c|c|}
\hline Diversity indices & Semi-deciduous forest & $\begin{array}{c}\text { Guinean } \\
\text { savanna }\end{array}$ & $\begin{array}{c}\text { Sudanian } \\
\text { savanna }\end{array}$ \\
\hline Specific richness & 46.0 & 10.0 & 21.0 \\
\hline Shannon index & 5.15 & 2.64 & 3.83 \\
\hline Evenness & 0.93 & 0.80 & 0.87 \\
\hline
\end{tabular}

Table 7. Variability of species diversity

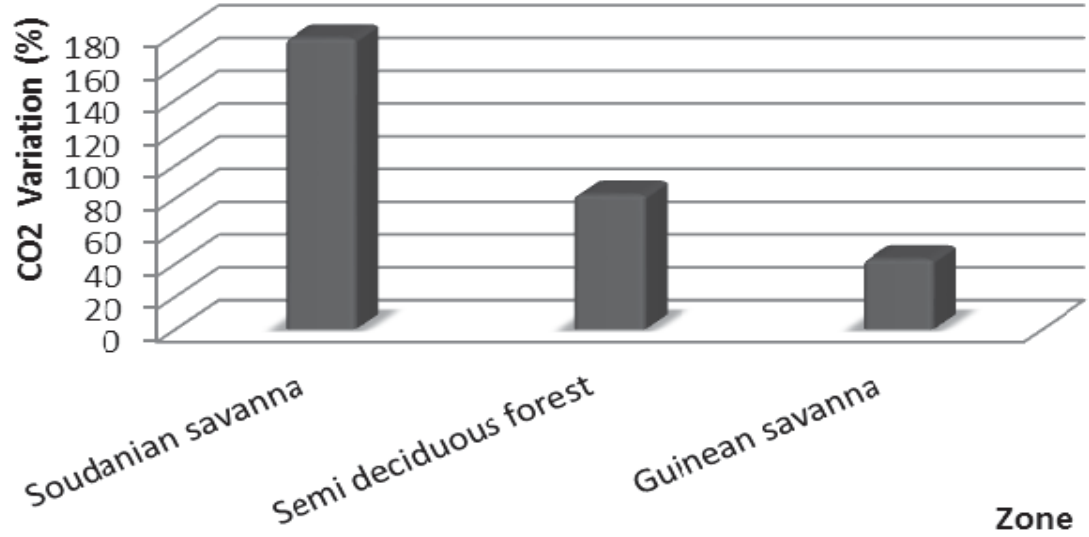

Fig. 9. Species number according to depth 
Species richness $\left(N_{0}\right)$ which represents the total number of species; Shannon index: $I_{s h}=-\sum_{i=1}^{n} p i \log (p i)$ [Equation 6], where $p i=\frac{q i}{Q}$, qi representing the population of $i$ species and $Q$ being the total population. Its value increases when the number of species of the collection gets large or reveals slightly different frequencies between the species encountered.

\section{Environmental policies impacting charcoal production}

The charcoal production has brighter days ahead to damage more the natural ecosystems and contributes more to the loss of the biodiversity because of the failure of the forestry policy (Kokou \& Nuto, 2009). This authors show that there is a very significant decoupling between the policies and laws enforcement by the officials in charge of the protection and management of the environment. The direct consequence of this situation is the anarchical trees logging by the farmers for firewood and charcoal supply. Moreover the producers concerned at first place by the protection of the ecosystem are not aware of any laws. They are not adapted to actual realities in terms of protection and regulation of forest products movements. Also, land ownership legislative applied in Togo does not allow the government to conduct checking exercises on exploitation lands. Indeed, the customary land ownership regulations come from the clan organisation of the society which is characterized by the occupation of the autonomous territories by communities made up of all the descendants of a common ancestor. The lands located within the limits of clan's territories are at the disposal of all the members of the same lineage. They can clear the land for farming and produce charcoal when need be. Up to 2007, Togo does not have real forest resources laws. This explains the confusion that comes at the level of the sawyer and woodcutters arrests. There is a lack of modern material means which are needed by public services for the protection and the management of the environment. Though the existence of an Intervention Fund for the Environment, the public services which handle the management of the environment do not have financial means to carry out their daily duties. No coordination between different departments, while the Agricultural Ministry encourages the populations to develop cotton production by practising intensive slash-and-burn farming, the Ministry of Environment banned this technique. Inside the Ministry of Environment, the forest technical directions work independently and without an effective coordination. These administrative structures imply an overlapping of competences, a harmful competition, a weakening of responsibilities, a loss of means and opacity of responsibilities vis-à-vis the population and other public services. An intricate relationship does exist amongst the forest officials on one hand, and between these officials and the rural populations on the other hand. One of the directions is the ODEF created in 1971 to exploit process and sell forest products. In perspective, the Government intended to entrust the production and the marketing of charcoal to this institution. Unfortunately, ODEF gave up the job with time because of the financial and material difficulties that it encountered. In this context, these structural and organisational problems become subsided by the social ones. Some officials work for themselves and do not really bother for their being in the service only at the time of control by their seniors. Moreover, some recruit charcoal producers who produce charcoal for them. Therefore, policies and laws do not have any influence on charcoal production. 
The lack of enforcement that followed increased the pressure on plant cover and the direct consequence being uncoordinated trees logging. The government does not play any role to regulate the charcoal market and does not influence the speculations. This situation is not specific to Togo but consistent with most countries in the sub-region (Kersten et al., 1998).

\section{Conclusion}

The production of charcoal has increased considerably these past years. The current study enabled to know the impact of this activity on the natural ecosystems in Togo. It results that the average annual consumption per inhabitant must be reassessed. Fixed at 59 $\mathrm{kg} /$ person/year in 1991 and at $62 \mathrm{~kg} /$ person/year in 2007, at present it have reached 75 $\mathrm{kg} /$ person/year. The deforestation rate caused by this activity is also rising, 2,799,759 tons/year. There is therefore an uncertain future for the forestry sector of Togo, since the production is not followed by a rational reforestation program. The protected areas in the country are therefore severely affected leading to irreversible degradation. The preferential species are overexploited and some of them are likely to disappear. The soil and its biodiversity (fauna) are highly damaged by fire and carbonization.

But, despite the negative effects that its production causes, charcoal can nevertheless be seen as a product offered gracefully by nature and constitutes a future energy, capable of meeting energy and environmental challenges of the XXIst century. In this situation, the development, the rationalization and the modernisation of the biomass uses, are therefore essential to a sustainable management of resources and to their renewal. It is therefore urgent to review the global policy concerning the setting of prices for energy wood to take into account, on the one hand, the increasing erosion situation of the forestry resources and to well develop the energy wood. It is also urgent to introduce a more adapted modern technique of carbonization such as the improved kiln used in Casamanse in Senegal Republic, called "Casamanse" kiln.

\section{Acknowledgements}

This study has been sponsored by African Academy for Sciences (AAS) and the African Forest Research Network (AFORNET).

\section{References}

AFNOR NF X 31-100. (1992). Soil quality. Sampling, Soil sampling method. Paris.

Banana, A.Y. \& Gombia-Ssembajjwe, W. (1996). Successful Forest Management: The importance of Security of Tenure and Rule Enforcement in Uganda Forest, International Forestry Ressources and Institutions Research Program Series, Bloomington, United States

Chen, L.; Heerink, N.; \& Berg, M.V.D. (2005). Energy consumption in rural China: A household model for three villages in Jiangxi Province. Ecological Economics, Vol. 58, pp. $407-420$

Coineau, Y. (1974). Introduction à l'étude des microarthropodes du sol et de ses annexes. Document pour l'enseignement pratique de l'écologie, Doin, Paris

Ern, H. (1979). Die Vegetation Togos. Gliederung, Gefährdung, Erhaltung. Willdenowia, Vol. 9, pp. 295-312 
Fontodji, K.J. (2007). Impact de la production du charbon de bois sur les propriétés du sol et la biodiversité au Togo. DEA Report, Univeriity de Lomé, Togo

Fontodji, K.J. ; Mawussi, G. ; Nuto Y. \& Kokou, K. (2009). Effects of charcoal production on soil biodiversity and soil physical and chemical properties in Togo, West Africa. International Journal of Biolology and Chemistry Sciences Vol. 3, No. 5, pp. 870-879

Girard, P. (2002). Charcoal production and use in Africa: What future? Unasylva 211: 30-34

Geist, H. J. \& Lambin, E.L (2002). Proximate causes and underlying driving forces of tropical deforestation. BioScience, 52(2): 143-150.

Kersten, I.; Baumbach, G.; Oluwolé, A., F.; Oboch, I. B. \& Ogunsola, O.J. (1998). Urban and rural fuelwood situation in the tropical rain forest area of South-West Nigeria. Energy Vol. 23, No. 10, pp. 887-898.

Kokou, K. \& Nuto, K. (2009). Assessment of Charcoal Production and Impact of Environmental Policies in Limited Forest Resources Countries: The case of Togo, West Africa. Discovery \& Innovation Vol. $21 \mathrm{n}^{\circ} 1 / 2$.

Kokou K.; Nuto, Y. \& Atsri, H. (2009). Impact of charcoal production on woody plant species in West Africa: A case study in Togo. Scientific Research and Essay Vol.4 (8), pp. 881893.

Lebrun, J.P. \& Stock, A.L. (1991-1997). Enumération des plantes à fleurs d'Afrique tropicale. 4 volumes. Conservatoires et Jardin Botanique de la ville de Genève.Makundi, W.R., 2001. Potential and cost of carbon sequestration in the Tanzanian Forest Sector. Mitigation and Adaptation Strategies for Global Change, $6: 335-353$.

Ministère des Mines, de l'Energie et des Postes et Télécommunication (MMEPT) (2002). Analyse, stratégie et programme d'action du sous-secteur des énergies traditionnelles. Rapport national, $100 \mathrm{p}$.

Neke, KS; Owen-Smith, N. \& Witkowski, T.F. (2006). Comparative resprouting response of Savanna woody plant species following harvesting: the value of persistence. Forest Ecology and Management 232: 114-123.

Ninnin, B. (1994). Eléments d'économie spatiale des énergies traditionnelles: Application au cas de cinq pays sahéliens : Burkina Faso, Gambie, Mali, Niger, Sénégal. Programme Régional pour le Secteur des Energies Traditionnelles (RPTES), Africa Region, World Bank, Washington, DC.

Ouédraogo, A. (2006). Diversité et dynamique de la végétation ligneuse de la partie orientale du Burkina Faso. Thèse de Doctorat, Univ. Ouagadougou, 195 p.

Schinner, F.; Ohlinger, R.; Kandeler, E. \& Margesin, R. (1996). Methods in Soil Biology. Springer Verlang Berlin Heidelberg; 92-98.

Soltner, D. (1982). Les Bases de la Production Végétale (11e édn). Collection Sciences et Techniques Agricoles: Sainte-Gemmes-Sur-Loire.

Thiam, T.A. (1991). Etude de marché des produits forestiers ligneux au Togo. Projet PNUD/FAO. Rapport, 225p.

Walkley, A. (1947). A critical examination of a rapid method for determining organic carbon in soils-effect of variations in digestion conditions and of inorganic constituents. Soil Science, 63(4): 251-264 


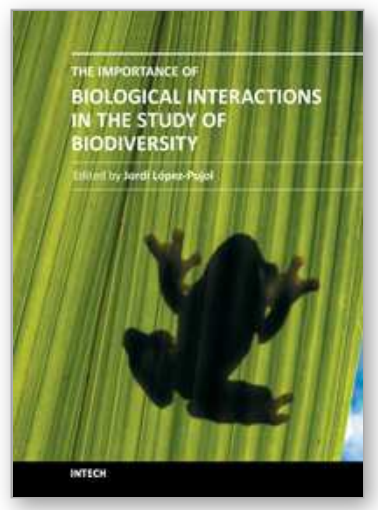

\section{The Importance of Biological Interactions in the Study of Biodiversity}

Edited by Dr. Jordi LÃ $\tilde{\beta}^{3}$ ez-Pujol

ISBN 978-953-307-751-2

Hard cover, 390 pages

Publisher InTech

Published online 22, September, 2011

Published in print edition September, 2011

The term biodiversity defines not only all the variety of life in the Earth but also their complex interactions. Under the current scenario of biodiversity loss, and in order to preserve it, it is essential to achieve a deep understanding on all the aspects related to the biological interactions, including their functioning and significance. This volume contains several contributions (nineteen in total) that illustrate the state of the art of the academic research in the field of biological interactions in its widest sense; that is, not only the interactions between living organisms are considered, but also those between living organisms and abiotic elements of the environment as well as those between living organisms and the humans.

\section{How to reference}

In order to correctly reference this scholarly work, feel free to copy and paste the following:

Jérémie Kokou Fontodji, Honam Atsri, Kossi Adjonou, Aboudou Raoufou Radji, Adzo Dzifa Kokutse, Yaovi Nuto and Kouami Kokou (2011). Impact of Charcoal Production on Biodiversity in Togo (West Africa), The Importance of Biological Interactions in the Study of Biodiversity, Dr. Jordi LÃ ${ }^{3}$ pez-Pujol (Ed.), ISBN: 978-953307-751-2, InTech, Available from: http://www.intechopen.com/books/the-importance-of-biologicalinteractions-in-the-study-of-biodiversity/impact-of-charcoal-production-on-biodiversity-in-togo-west-africa-

\section{INTECH}

open science | open minds

\section{InTech Europe}

University Campus STeP Ri

Slavka Krautzeka 83/A

51000 Rijeka, Croatia

Phone: +385 (51) 770447

Fax: +385 (51) 686166

www.intechopen.com

\section{InTech China}

Unit 405, Office Block, Hotel Equatorial Shanghai

No.65, Yan An Road (West), Shanghai, 200040, China 中国上海市延安西路65号上海国际贵都大饭店办公楼 405 单元

Phone: +86-21-62489820

Fax: $+86-21-62489821$ 
(C) 2011 The Author(s). Licensee IntechOpen. This chapter is distributed under the terms of the Creative Commons Attribution-NonCommercialShareAlike-3.0 License, which permits use, distribution and reproduction for non-commercial purposes, provided the original is properly cited and derivative works building on this content are distributed under the same license. 